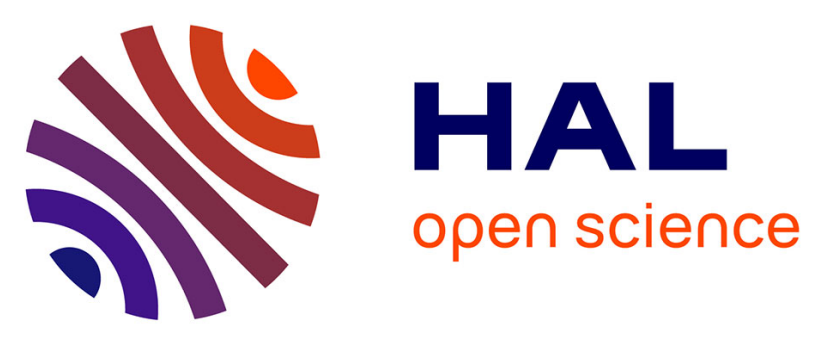

\title{
Trends in concentrations of selected metalloid and metals in two bivalves from the coral reefs in the SW lagoon of New Caledonia
}

Laetitia Hédouin, Paco Bustamante, Carine Churlaud, O. Pringault, Renaud Fichez, Michel Warnau

\section{To cite this version:}

Laetitia Hédouin, Paco Bustamante, Carine Churlaud, O. Pringault, Renaud Fichez, et al.. Trends in concentrations of selected metalloid and metals in two bivalves from the coral reefs in the SW lagoon of New Caledonia. Ecotoxicology and Environmental Safety, 2009, 72 (2), pp.372- 381. 10.1016/j.ecoenv.2008.04.004 . hal-00336151

\section{HAL Id: hal-00336151 https://hal.science/hal-00336151}

Submitted on 2 Nov 2008

HAL is a multi-disciplinary open access archive for the deposit and dissemination of scientific research documents, whether they are published or not. The documents may come from teaching and research institutions in France or abroad, or from public or private research centers.
L'archive ouverte pluridisciplinaire HAL, est destinée au dépôt et à la diffusion de documents scientifiques de niveau recherche, publiés ou non, émanant des établissements d'enseignement et de recherche français ou étrangers, des laboratoires publics ou privés. 


\section{Trends in concentrations of selected metalloid and metals in two}

2 bivalves from the coral reefs in the SW lagoon of New Caledonia

3

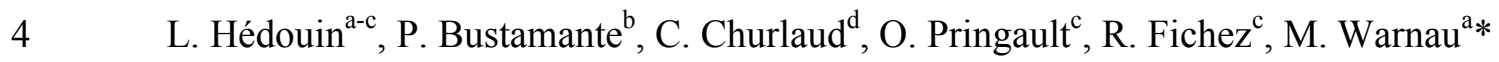

5

$6{ }^{a}$ International Atomic Energy Agency - Marine Environment Laboratories (IAEA-MEL), 4

7 Quai Antoine 1er, MC-98000 Principality of Monaco

8 b Littoral, Environnement et Sociétés (LIENSs), UMR 6250, CNRS-Université de La

9 Rochelle, 2 rue Olympe de Gouges, F-17042 La Rochelle cedex 01, France

10 c Institut de Recherche pour le Développement, UR 103 Camélia, BP A5, 98848 Nouméa,

11 New-Caledonia

12 d Centre Commun d'Analyses (CCA), Université de La Rochelle, 5 Perspectives de l'Océan, 13 F-17071 La Rochelle, France

14

15

16

17

*Corresponding author: Dr. Michel Warnau

Present address: $\quad$ LIENSs, UMR6250, CNRS-Université de La Rochelle 


\section{Abstract}

24 The concentrations of 9 elements (Ag, As, Cd, Co, Cr, Cu, Mn, Ni and $\mathrm{Zn}$ ) were measured 25 in the oyster Isognomon isognomon and the edible clam Gafrarium tumidum from different 26 sites along the SW New Caledonian coast which is subjected to important chemical inputs due 27 to intense land-based mining activities (New Caledonia is the third world producer of nickel). 28 Results indicate that concentrations in the two organisms mirrored the geographical 29 differences in contamination levels as established through element analyses in sediment. On 30 the basis of organism analyses, two out of the seven investigated stations can be considered as 31 relative "reference" sites, except for As, for which very high levels were detected in clam and 32 oyster tissues (up to $441 \mu \mathrm{g} \mathrm{g}^{-1}$ dry wt for clams). Overall, our results indicate that both 33 tropical organisms investigated could be used as valuable bioindicator species for surveying 34 metal contamination in the coastal waters of New Caledonia with reasonable perspectives of 35 wider application to other coral reef environments.

37 Keywords: Tropical Environment, Metals, Bioindicators, Mining activities 


\section{Introduction}

Surrounded by a barrier reef of $1600 \mathrm{~km}$, the New Caledonia lagoon is one of the largest in the world (Labrosse et al., 2000). However, the lagoon of New Caledonia is subjected to important anthropogenic inputs of metals mainly due to intense land-based $\mathrm{Ni}$ mining activities but also to urban development and lack of efficient wastewater treatment. Open-cast mining exploitation presently constitutes the major economical resource of the Territory and results in important coastal discharges of metals, which constitute a threat to coral reef ecosystems (Labrosse et al., 2000). Recently, more efficient extraction processes based on acidic extraction (viz lixiviation) have been developed (Mihaylov et al., 2000; Goro-Nickel, 2001), making the extraction from low $\mathrm{Ni}$ grade ores (limonite) possible. The acidic extraction of metals is not Ni-selective and makes also soluble all other ore-contained byproduct metals. Therefore, the lixiviation process will obviously lead to an increased multielemental contamination of the coastal marine environment.

Although mining activities are rising up in the island, studies reporting concentrations or behaviour of metals in marine organisms from New Caledonia are scarce (Monniot et al., 1994; Bustamante et al., 2000; Labrosse et al., 2000; Hédouin et al., 2007). In this context, acquisition of reliable and relevant data in the New Caledonian lagoon is a strong priority and 56 the development and implementation of risk assessment studies and metal monitoring 57 programme is expected by the local authorities.

58 Among the approaches used to assess environmental contamination, the usefulness of 59 bioindicator species is now well established. Marine organisms provide valuable information 60 on the geographical and temporal variations of the bioavailable metal concentrations in their 61 environment (eg, Rainbow, 1995; Warnau et al., 1998). Ideally, selected bioindicators should 62 display a simple relationship between metals accumulated in their tissues and the ambient 
metal concentrations. This should be true regardless of location and environmental conditions considered.

Molluscs have been extensively used in temperate regions (eg, Goldberg et al., 1983; Rainbow, 1995), whereas little attention has been paid to the identification of bioindicators specifically adapted to tropical and sub-tropical regions (Phillips, 1991) despite the constant increase in industrial and human activities. Some efforts were devoted to the extension of the Mussel Watch to the Asia/Pacific and Latin America regions (see eg, UNU, 1994; IMWC, 1995), using bivalves such as Saccostrea spp., Crassostrea spp. and Perna spp. as bioindicators. However, none of the above-cited species is present in sufficient abundance along the New Caledonia coasts to be considered as a useful candidate to monitor local contamination. Hence, other tropical organisms have to be selected. In this context, recent studies screened metal concentrations in a variety of local marine organisms from different areas of the New Caledonian lagoon with contrasting contamination status (Breau, 2003; Hédouin, 2006; Hédouin et al., 2006; 2007). The latter studies showed that two bivalves, namely the oyster Isognomon isognomon and the edible clam Gafrarium tumidum, are satisfying the basic ecological and ecotoxicological requirements to be met by a bioindicator species sensu Moore (1966) and Phillips (1990b). Among others, metal bioaccumulation and retention capacity of $G$. tumidum and I. isognomon exposed via different pathways (seaweater, food, and sediment) were characterized in controlled conditions, including the relationships between metals concentrated in the bivalve tissues and the ambient metal concentrations (Hédouin 2006; Hédouin et al., 2006; 2007; submitted). Results indicate that both species are promising bioindicator candidates for tropical environments.

The aim of the present study was to further assess, in the field, the reliability of these two species as sentinel organisms and to provide information on the degree of contamination of selected elements of local concern (Ag, As, Cd, Co, Cr, Cu, Mn, Ni, Zn) in different locations 
along the SW coast of New Caledonia. Results presented in this paper also provide baseline data for future monitoring programmes.

\section{Materials and methods}

\section{1. $\quad$ Sampling sites}

The sampling stations were selected according to supposedly contrasting contamination status (Fig. 1). Oysters were collected in the subtidal zone of Maa Bay, Koutio Bay, Boulari Bay and Grande Rade $\left(\mathrm{GR}_{\mathrm{S}}\right)$. Maa Bay is subjected to low anthropogenic and terrigenous inputs and was considered as the relative "reference" station for oysters. Koutio Bay is influenced by inputs of domestic wastes from Noumea City and by the occurrence of an important rubbish dump. Boulari Bay is under the influence of La Coulée River that delivers important inputs of lateritic materials to the lagoon due to soil erosion of closed mine sites. Grande Rade $\left(\mathrm{GR}_{\mathrm{S}}\right)$ is subjected to anthropogenic inputs from the Ducos industrial zone and the metallurgic factory "Société Le Nickel” (SLN).

For clams, three intertidal sampling stations were selected: Ouano Beach, Dumbéa Bay and Grande Rade $\left(\mathrm{GR}_{\mathrm{I}}\right)$. Ouano Beach is situated $100 \mathrm{~km}$ northward from Noumea, and is not influenced by industrial activities; it was considered as the "reference" station for clams. Grande Rade $\left(\mathrm{GR}_{\mathrm{I}}\right)$ is subject to anthropogenic inputs from the SLN factory (scoria and waters), from the Shell Pacific factory (effluents) and from domestic discharges. Dumbéa Bay is an estuarine bay, influenced by waters from La Dumbéa River and subjected to terrigenous inputs.

\subsection{Organisms}

The clam Gafrarium tumidum was collected by handpicking in the intertidal stations. The oyster Isognomon isognomon is associated with rocky substrata at depth ranging from 2 to 25 $\mathrm{m}$ and were collected by SCUBA diving. All the organisms $(n=6$ per species per station $)$ 
112 were collected from October to November 2004 (mean water temperature: $25.6 \pm 0.8^{\circ} \mathrm{C}$ ) to

113 reduce as much as possible the variability of element concentrations due to season or sexual

114 cycle. Body size is well-known to affect metal concentrations in organisms (eg, Boyden,

115 1977; Warnau et al., 1995); therefore only samples with shell width longer than $35 \mathrm{~mm}$ for $G$.

116 tumidum (Hédouin et al., 2006) and shell length longer than $70 \mathrm{~mm}$ for I. isognomon (Metian,

117 2003) were selected for analysis. Collected clams (mean $\pm \mathrm{SD}, \mathrm{n}=18$ ) measured $38.1 \pm 2.8$

$118 \mathrm{~mm}($ width) and weighed $22.7 \pm 4.9 \mathrm{~g}$; oysters (mean $\pm \mathrm{SD}, \mathrm{n}=24)$ measured $98 \pm 13 \mathrm{~mm}$

119 (length) and weighed $36.9 \pm 13.2 \mathrm{~g}$. Back to the laboratory, the bivalves were kept for $24 \mathrm{hrs}$

120 in 301 of seawater from the same sampling station to allow for depurating gut contents and

121 particulate material present in the mantle cavity. Three body compartments for the clams

122 (digestive gland, gills and remaining soft parts) and four body compartments for the oysters

123 (visceral mass, gills, adductor muscle and remaining soft parts) were removed from the shells.

124 The separated body compartments were weighed (wet wt), dried at $60^{\circ} \mathrm{C}$ until constant

125 weight, and weighed again (dry wt). They were then stored in acid-washed, hermetically

126 sealed PET containers until analysis for their metal contents.

\section{$127 \quad$ 2.3. Sediments}

128 In parallel to organisms, superficial sediments (top 3-cm layer) were analysed in all the

129 sampling stations (Fig. 1), except in Dumbéa Bay and in Grande Rade $\left(\mathrm{GR}_{\mathrm{S}}\right)$ (samples lost

130 during diving). Sediments were stored in acid-washed PET bags until return to the laboratory;

131 they were then dried at $60^{\circ} \mathrm{C}$ until constant weight (5 days). In order to eliminate

132 heterogeneous materials (stones, fragment of corals), sediments were sieved (1-mm mesh 133 size) prior to analysis for their metal contents. 


\subsection{Sample preparation and analysis}

135 Aliquots of the biological samples $(0.1$ to $0.5 \mathrm{~g})$ and of the dried sediment samples $(0.5 \mathrm{~g})$ 136 were digested using a 3:1 (v:v) $65 \% \mathrm{HNO}_{3}$ - $30 \% \mathrm{HCl}$ mixture (Merck, suprapur quality).

137 Acidic digestion of the samples was carried out overnight at room temperature, then using a $138 \mathrm{MARS}^{\circledR} \mathrm{V}$ microwave (30 min with constantly increasing temperature up to $100^{\circ} \mathrm{C}$ for 139 sediment and up to $115^{\circ} \mathrm{C}$ for biota, then $15 \mathrm{~min}$ at this maximal temperature). These 140 conditions allowed for a complete digestion of the biological matrices and a strong although 141 not total (highly refractory humic acids may resist) leaching of the sediment (eg, Coteur et al.,

142 2003; Dalto et al., 2006). Each sample was eventually diluted to 30 to $50 \mathrm{ml}$ with milli-Q 143 water according to the amount of sample digested.

144 Elements were analysed using a $\operatorname{Varian}^{\circledR}$ Vista-Pro ICP-OES (As, Cr, Cu, Mn, Ni, and Zn) 145 or a $\operatorname{Varian}^{\circledR}$ ICP-MS Ultra Mass 700 (Ag, Cd and Co). Three control samples (two Certified 146 Reference Materials -CRMs- and one blank) treated and analysed in the same way as the 147 samples were included in each analytical batch. CRMs were dogfish liver DOLT-3 (NRCC) 148 and lobster hepatopancreas TORT-2 (NRCC). The results were in good agreement with the 149 certified values given for the CRMs and indicated the following recoveries (in \%): 103 (Ag), $15098(\mathrm{As}), 103(\mathrm{Cd}), 112(\mathrm{Co}), 79(\mathrm{Cr}), 95(\mathrm{Cu}), 84(\mathrm{Mn}), 113(\mathrm{Ni})$, ands $106(\mathrm{Zn})$. The 151 detection limits $\left(\mu \mathrm{g} \mathrm{g}^{-1}\right.$ dry wt) were $10.1(\mathrm{As}), 0.8(\mathrm{Cr}), 0.5(\mathrm{Cu}), 0.04(\mathrm{Mn}), 1.1(\mathrm{Ni})$ and 0.7 $152(\mathrm{Zn})$ for ICP-OES and $0.1(\mathrm{Ag}), 0.3(\mathrm{Cd})$ and $0.03(\mathrm{Co})$ for ICP-MS. Mean element 153 concentrations are given on a dry weight basis $\left(\mu \mathrm{g} \mathrm{g}^{-1}\right.$ dry wt).

\subsection{Statistical analysis}

155 Comparisons of the data were performed using 1- or 2-way analysis of variance 156 (ANOVA) followed by the multiple comparison test of Tukey (Zar, 1996). Two-way 157 ANOVA was used with sampling location and body compartment as fixed factors. The variability explained by each factor and their interaction was derived from the sum of squares 
159 (Warnau et al., 1998). The level of significance for statistical analyses was always set at $\alpha=$ $160 \quad 0.05$.

\section{3. Results}

162

163

164

165

166

167

168

169

\subsection{Sediments}

Table 1 shows the element concentrations measured in the sediment collected in the different stations. Except for $\mathrm{Ag}$, for which comparison among stations was not possible due to concentrations always under the detection limit, statistical analyses indicated contrasting element concentrations among stations. Boulari Bay and Grande Rade $\left(\mathrm{GR}_{\mathrm{I}}\right)$ displayed the highest concentrations for all elements. Concentrations in all elements were always significantly higher in Grande Rade $\left(G_{\mathrm{I}}\right)$ than in Ouano Beach ( $\left.\mathrm{p}_{\text {Tukey }}<0.0001\right)$. Concentrations in sediment from Boulari Bay were significantly higher (up to 1 order of magnitude) than those measured in the other stations where oysters were also sampled.

\subsection{The oyster Isognomon isognomon}

Among the two factors considered (body compartment and sampling location) and their interaction, the sampling location explained the major part of the variability observed for As, $\mathrm{Cd}, \mathrm{Cr}$ and $\mathrm{Ni}$ (accounting for 16 to $70 \%$ of the global variance) (Tables 2 and 3, Fig. 2A) whereas the body compartment was the predominant factor explaining the variability observed for $\mathrm{Cu}(29 \%), \mathrm{Mn}(49 \%)$ and $\mathrm{Zn}(36 \%)$. Significant interaction between body compartment and sampling location factors was detected for all elements except $\mathrm{Mn}$, and accounted for 14 to $44 \%$ of the global variance, indicating that geographical variation of measured concentrations was dependent upon the body compartment considered. For all elements, an important part of the variation was associated to the residual term, ranging from 12 to $58 \%$, indicating that other, non-investigated factors (biological and/or environmental 
182 factors) were also influencing metal concentrations in the oyster soft tissues (see also section $183 \quad 3.3)$

184

185

\subsubsection{Geographical variation}

The sampling location significantly affected the concentrations of all studied elements in the body compartments of I. isognomon (2-way ANOVA, pampling locations $_{2} 0.0001$ ), except for Mn for which calculated probability was borderline $(\mathrm{p}=0.054)$ (Table 3, Fig. 2A). Multiple comparison tests on the mean concentrations indicated that one sampling location displayed generally the highest concentrations for one or several elements, whereas the three other locations did not show significant difference in element concentrations, except for Mn (no significant difference among none of the sampling stations) and As (all stations significantly different from each others).

Concentrations of $\mathrm{Co}$ and $\mathrm{Ni}$ in the oysters were significantly higher in Boulari Bay than in Maa Bay $\left(\mathrm{p}_{\text {Tukey }} \leq 0.001\right.$; Table 2, Fig. $\left.2 \mathrm{~A}\right)$. Oysters from Grande Rade $\left(\mathrm{GR}_{\mathrm{S}}\right)$ displayed significantly higher $\mathrm{Ag}$ and $\mathrm{Cu}$ concentrations than those measured in Maa Bay $\left(\mathrm{p}_{\text {Tukey }} \leq 0.01\right)$ whereas the highest $\mathrm{Cr}$ concentrations were measured in oysters from Koutio Bay ( $\mathrm{p}_{\text {Tukey }} \leq$ 0.05). In contrast to all other elements, As and $\mathrm{Zn}$ concentrations were higher in oysters from Maa Bay.

Geographical variation of the element concentrations in the whole-soft parts of the oysters (reconstructed data) were tested using 1-way ANOVA and Tukey test. Results were similar to those from the 2-way ANOVA performed on body-compartment specific concentrations, except for $\mathrm{Cd}$ and $\mathrm{Zn}$. For these two latter elements, no significant difference was observed among whole soft parts in the four sites for $\mathrm{Cd}$ and between Maa Bay and Grande Rade $\left(\mathrm{GR}_{\mathrm{S}}\right)$ for $\mathrm{Zn}$ (Table 2). The particular opposite pattern of As and $\mathrm{Zn}$ displaying highest concentrations in Maa Bay (up to $77 \mu \mathrm{g}$ As $\mathrm{g}^{-1}$ dry wt and 13,817 $\mu \mathrm{g} \mathrm{Zn} \mathrm{g}{ }^{-1}$ dry wt) was confirmed in whole soft parts data treatment. 


\subsubsection{Body distribution}

Multiple comparison tests performed after 2-way ANOVA on the mean concentrations in

each body compartment (all sampling locations together) indicated that the concentrations of all elements were lower in the adductor muscle than in the other body compartments (Fig. 2A). Generally, concentrations in gills and visceral mass were not significantly different, but significantly higher than in the other body compartments.

213 In terms of distribution of total element load among body compartments, visceral mass

214 and remaining soft parts contained the highest proportion of the elements. Body distribution

215 did not differ among sampling locations, except for Ag which occurred in higher proportion

$216(43 \%)$ in the gills of oysters from Grande Rade $\left(\mathrm{GR}_{\mathrm{S}}\right)$ compared to those from the other 217 stations (5 - $24 \%)$.

\subsection{The clam Gafrarium tumidum}

219 The two-way ANOVA performed on the whole set of data indicated that, with the exception of $\mathrm{Mn}$ and $\mathrm{Zn}$, the sampling location was the predominant factor affecting element concentrations, accounting for 23 to $84 \%$ of the global variance (Tables 3 and 4, Fig. 2B).

222 The ranking of sampling stations by order of decreasing concentration depended on the 223 considered clam body compartment. In the case of $\mathrm{Ag}, \mathrm{Cd}, \mathrm{Co}, \mathrm{Cr}, \mathrm{Mn}, \mathrm{Ni}$ and $\mathrm{Zn}, 35$ to $61 \%$ 224 of the element concentration variability was due to undetermined factor(s) (residual term).

It is noteworthy that the elements for which the residual terms are the highest $(\mathrm{Cd}, \mathrm{Co}, \mathrm{Cr}$, $\mathrm{Mn}$ ) both in clams and oysters are those that are co-occurring in Ni-ores. Therefore, it is most plausible that the undetermined factor(s) are related to mining activities, either directly (eg, nature of exploited soils in different areas) or indirectly (eg, climatic factors such as rains temporarily enhancing soil-erosion and riverine inputs). 


\subsubsection{Geographical variation}

The mean concentrations of all elements measured in clams varied significantly according to the sampling locations (2-way ANOVA, $p_{\text {sampling locations }}$ always $\leq 0.002$ ) (Tables 3 and 4,

233 Fig. 2B). Results showed significant differences between Ouano Beach and Grande Rade

$234\left(\mathrm{GR}_{\mathrm{I}}\right)$ for $\mathrm{Ag}, \mathrm{Cd}, \mathrm{Cr}, \mathrm{Cu}, \mathrm{Mn}, \mathrm{Ni}$ and $\mathrm{Zn}$, with the highest concentrations always found in

235 Grande Rade $\left(\mathrm{GR}_{\mathrm{I}}\right)$. In contrast the concentrations of As were significantly higher in Ouano

236 Beach compared to all the other locations ( $\mathrm{p}_{\text {Tukey }} \leq 0.001$; Table 4 and Fig. 2B).

237 Geographical variations were tested using 1-way ANOVA and Tukey test for the 238 reconstructed element concentrations in the whole-soft parts of the clams (Table 4). Results 239 were similar to those previously obtained with 2-way ANOVA performed on body240 compartment specific concentrations, except for Co which showed significant differences 241 among whole soft parts in the three sampling locations ( $\mathrm{p}_{\text {Tukey }}<0.05$ ). Similarly to oysters, As 242 levels in clams were highest in the "reference" station (Ouano Beach), reaching mean values 243 up to $441 \mu \mathrm{g} \mathrm{g}^{-1}$ dry wt.

\subsubsection{Body distribution}

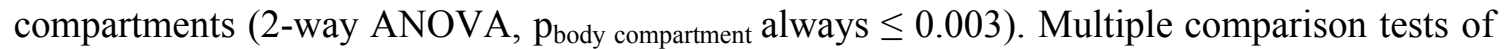

247 Tukey indicated that the concentrations of $\mathrm{Cd}, \mathrm{Cu}, \mathrm{Cr}, \mathrm{Mn}$ and $\mathrm{Zn}$ were significantly higher in 248 the digestive gland than in the other tissues $(\mathrm{p}<0.05$; Fig. 2B). Ag, As, Co and Ni 249 concentrations were similar in the digestive gland and the gills. No major difference was 250 found when considering body distribution in clams collected from Ouano Beach and Dumbéa 251 Bay. In these two stations, the remaining soft parts contained the main fraction (55 to $77 \%$ ) 252 of the total body burden for all elements. In contrast, in Grande Rade $\left(\mathrm{GR}_{\mathrm{I}}\right)$, the elements 253 were similarly distributed between the remaining soft parts and the digestive gland. 


\section{Discussion}

255 Sediments are a sink for marine contaminants (eg, Salomons et al., 1987) and their 256 element concentrations are often used to assess and monitor the contamination status of the 257 marine environment. According to this concept, Boulari Bay and Grande Rade $\left(\mathrm{GR}_{\mathrm{I}}\right)$ may be 258 considered as highly contaminated stations compared to Ouano Beach and Maa Bay. In turn, 259 the two latter ones may be defined as relatively non-contaminated stations (see Table 1). 260 However, it is now well known that sediment-associated concentrations are not necessarily 261 representative of the contaminant fraction that is bioavailable, viz the fraction of "direct 262 ecotoxicological relevance" for marine organisms (Phillips and Rainbow, 1993). Therefore, 263 the present study was carried out to assess the usefulness of the oyster Isognomon isognomon 264 and the clam Gafrarium tumidum as sentinel species over sediment for $\mathrm{Ag}, \mathrm{As}, \mathrm{Cd}, \mathrm{Co}, \mathrm{Cr}$, $265 \mathrm{Cu}, \mathrm{Mn}, \mathrm{Ni}$ and $\mathrm{Zn}$ contamination in the SW lagoon of New Caledonia.

266 In agreement with sediment analyses, Maa Bay can also be considered as a relative 267 reference site when considering element measurements in the oyster I. isognomon for all 268 elements, except As and $\mathrm{Zn}$. The low element concentrations reported in the oysters from this 269 bay are in the same range as those reported in the literature for Isognomon spp. as well as in 270 other oyster genera from clean areas (see Table 5).

271 The elevated concentrations of $\mathrm{Co}$ and $\mathrm{Ni}$ measured in oysters from Boulari Bay strongly 272 suggest that a high degree of mining-related contamination occurs in this area, most probably 273 due to releases from surrounding mines and mining-enhanced erosion of the soils. This was 274 further confirmed by the high concentrations of $\mathrm{Co}, \mathrm{Cr}, \mathrm{Mn}$ and $\mathrm{Ni}$ measured in the sediment 275 from Boulari Bay. However, element analysis in oyster tissues showed that other stations, not 276 identified through sediment analysis, are also highly contaminated for some elements, 277 especially Maa Bay for $\mathrm{As}$ and $\mathrm{Zn}$ and Grande Rade $\left(\mathrm{GR}_{\mathrm{S}}\right)$ for $\mathrm{Ag}$. The elevated 278 concentrations recorded in oysters suggest that Maa Bay would be subjected to agrochemical 
inputs (eg, Francesconi et al., 1999; Warnau et al., 2007) and Grande Rade $\left(\mathrm{GR}_{\mathrm{S}}\right)$ to important

280 domestic wastewater discharges (eg, Martin et al., 1988; Sañudo-Willhelmy and Flegal, 281 1992).

282 With the exception of As, element concentrations in the clams G. tumidum collected from

283 Ouano Beach were always lower than in those from Grande Rade $\left(\mathrm{GR}_{\mathrm{I}}\right)$. This is in agreement

284 with the results obtained from sediment analysis. Concentrations measured in the clams from

285 Ouano Beach were in the same range as those reported for clean areas from other tropical

286 zones (see Table 5). Ouano Beach may thus be considered as a relatively clean station for all

287 elements considered, except for As. In contrast, Grande Rade $\left(\mathrm{GR}_{\mathrm{I}}\right)$ can be defined as a highly 288 contaminated station for $\mathrm{Ag}, \mathrm{Cr}, \mathrm{Cu}, \mathrm{Mn}, \mathrm{Ni}$ and $\mathrm{Zn}$.

289 In this work, the distribution of the considered elements in bivalve tissues was also 290 investigated in order to possibly identify some organs that could be more sensitive than the 291 use of the whole soft parts and able to respond more rapidly to changes in element 292 contamination in the environment (eg, Warnau et al., 1996b; 1998; 1999). Among the body 293 compartments of the clam $G$. tumidum, the digestive gland displayed the highest 294 bioconcentration capacity. In addition, the concentrations measured in this organ easily 295 allowed discriminating the stations according to their contamination levels. Hence, this organ 296 could be proposed as a target for future biomonitoring programmes. In the oyster $I$. 297 isognomon, no clear trends could be observed in bioaccumulation and geographical 298 discrimination ability among the different body compartments. Consequently, in a future 299 biomonitoring programme, consideration of the whole soft parts of oysters could be 300 recommended.

301 The two investigated species accumulated some elements up to very high concentrations 302 compared to the concentrations generally reported in the literature (Table 5). These 303 particularities are discussed below. 
Ni concentrations measured in clams bear out the capacities of this species to accumulate

305 this metal. Indeed, Ni concentrations in clams from Grande Rade $\left(\mathrm{GR}_{\mathrm{I}}\right)$ were higher $(52 \pm 12$

$306 \mu \mathrm{g} \mathrm{g}^{-1}$ dry wt) by one order of magnitude than those usually reported in the literature for other

307 tropical clams (see Table 5). The high levels that we measured for $\mathrm{Cr}$ and $\mathrm{Ni}$ in sediment and

308 clams from Grande Rade $\left(\mathrm{GR}_{\mathrm{I}}\right)$ are obviously due to mining activities (presence of SLN

309 industry, which discharges wastes into the Rade) associated to mining-enhanced erosion of

310 lateritic soils, which are enriched in $\mathrm{Cr}$ and $\mathrm{Ni}$ (Labrosse et al., 2000).

311 Although scarcely available, As concentrations reported in the literature for tropical and

312 subtropical bivalves are generally lower than $30 \mu \mathrm{g} \mathrm{g}^{-1}$ dry wt $\left(<10 \mu \mathrm{g} \mathrm{g}^{-1}\right.$ dry wt if one

313 considers clams and oysters; see Table 5). However, two studies on sub-tropical areas

314 indicated elevated As concentrations in Isognomon spp from Florida $\left(37.3 \pm 6.9 \mu \mathrm{g} \mathrm{g}^{-1}\right.$ dry

315 wt) (Valette-Silver et al., 1999) and in the clam Circentia callipyga from the Gulf of Oman

316 (156 $\mathrm{g} \mathrm{g} \mathrm{g}^{-1}$ dry wt) (de Mora et al., 2004). In the present study, As was found to reach

317 extremely high concentrations in the clams from Ouano Beach $\left(441 \pm 84 \mu \mathrm{g} \mathrm{g}^{-1} \mathrm{dry}\right.$ wt)

318 compared to those observed in Grande Rade $\left(\mathrm{GR}_{\mathrm{I}}\right)\left(55 \pm 15 \mu \mathrm{g} \mathrm{g}^{-1}\right.$ dry wt) and in the oysters

319 from Maa Bay $\left(77 \pm 9 \mu \mathrm{g} \mathrm{g}^{-1}\right.$ dry wt). To the best of our knowledge, such high body

320 concentrations of As have never been reported in other clams. The Ouano Beach values were

321 in fact on the same order of magnitude than the highest As concentrations ever reported, such

322 as in the cirratulid polychaete Tharyx marioni which displays extremely high body

323 concentrations of total As (2000 $\mu \mathrm{g} \mathrm{g}^{-1}$ dry wt; Gibbs et al., 1983), the Mediterranean fan

324 worm Sabella spallanzanii which shows As concentrations higher than $1000 \mu \mathrm{g} \mathrm{g}^{-1}$ dry wt in

325 its branchial crown (Fattorini and Regoli, 2004) or the very high arsenic concentrations

326 monitored in muscles of edible fish (500 $\left.\mu \mathrm{g} \mathrm{g}^{-1} \mathrm{dry} w \mathrm{wt}\right)$ from the Bay of Cienfuegos, Cuba, a

327 few weeks after an accidental release of arsenate oxides from a local nitrogen fertilizer factory

328 in Dec 2001 (Fattorini et al., 2004; Warnau et al., 2007). However the reason for so high As 
concentrations in G. tumidum tissues is not clear. Some authors have reported that As

330 concentrations in organisms were related to the sediment concentrations (such as in

331 Scrobicularia plana; Langston, 1980). However no similar correlation was observed here. In

332 addition, laboratory experiments have shown that bivalves generally displayed a limited

333 capacity in accumulating As from seawater (eg, Ünlü and Fowler, 1979; Hédouin, 2006;

334 Gómez-Batista et al., 2007). Thus, the elevated As concentrations reported in this study would

335 be accumulated most probably from the diet of the organisms (Sanders et al., 1989; Gómez-

336 Batista and Warnau, unpubl. results). Accordingly, transfer along the food chain could be

337 proposed as the main route of uptake for As in bivalves, suggesting that food of both oysters

338 and clams are enriched in As in Maa Bay and Ouano Beach, compared to the other sampling

339 locations. Whereas some agricultural activities are carried out in Maa Bay, Ouano Beach is

340 rather subjected to waste discharges from shrimp aquaculture. Hence the important discharges

341 of N-enriched products (due to terrestrial leaching of fertilisers used for local agriculture or to

342 release of aquaculture food excesses) could locally modify the N:P ratio. In environments

343 with phosphate deficit relative to nitrogen, phytoplankton metabolises As much more easily

344 (Benson and Summons, 1981; Phillips, 1990a). This in turn may lead to enhanced trophic

345 transfer of As to filter-feeders and enhanced As accumulation in the tissues of the bivalves

346 (Warnau et al., 2007). Although further investigations are needed to validate such a

347 hypothesis in Maa Bay and Ouano Beach, the extremely high As levels measured in clam

348 tissues are of considerable interest because (1) G. tumidum is a seafood product in New

349 Caledonia and (2) little is known about the speciation of As in the tissues of this species

350 (Francesconi et al., 1999) which determines its potential toxicity to consumers (see eg, Kaise

351 and Fukui, 1992; Warnau et al., 2007).

352 I. isognomon displayed also very high $\mathrm{Zn}$ concentrations in Maa Bay and in Grande Rade

$353\left(\mathrm{GR}_{\mathrm{S}}\right)$, viz $13,817 \pm 6,621$ and $7,873 \pm 2,087 \mu \mathrm{g} \mathrm{g} \mathrm{g}^{-1}$ dry wt, respectively. Elevated 


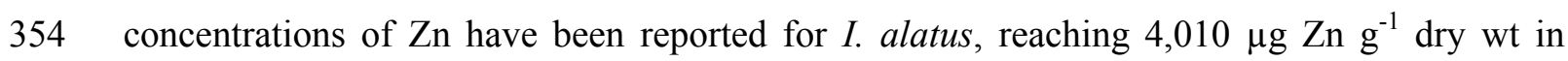

355 individuals collected in the Dominican Republic and $12,163 \mu \mathrm{g} \mathrm{g}^{-1}$ dry wt in the Guadeloupe

356 (see Table 5). Although, $\mathrm{Zn}$ is well known to be essential to organisms, acting for example as

357 a co-factor in numerous metalloenzymes (eg, Vallee and Falchuk, 1993), the amounts

358 accumulated are clearly far above the physiological needs of the bivalve. I. isognomon must

359 therefore possess a natural capacity to accumulate $\mathrm{Zn}$ up to very high levels while avoiding

360 subsequent toxicity. Such a mechanism could be for example the immobilization of $\mathrm{Zn}$ under

361 non-toxic forms in granules which are very slowly excreted (eg, Corrêa Junior et al., 2000).

362 Indeed, in many bivalves and especially in oysters, granules may contain up to $60 \%$ of the

363 total body load of Zn (Eisler, 1981).

$364 \mathrm{Ag}$ is well known as a highly toxic metal (eg, Warnau et al, 1996a; Ratte, 1999) and the

365 scarcity of data concerning Ag levels in tropical and subtropical organisms in general, and in

366 particular in clams and oysters, is therefore quite surprising (see Table 5). In this way, the

367 concentrations measured in the two investigated species (see Tables 2 and 4) can be

368 considered as baseline data for the New Caledonia lagoon as well as for other tropical

369 environments. Clams and oysters collected from Grande Rade displayed quite elevated Ag

370 concentrations ( $33 \pm 13$ and $33 \pm 7 \mu \mathrm{g} \mathrm{g}^{-1}$ dry wt, respectively), which are one to two orders

371 of magnitude higher than those measured in bivalves from the "reference" stations (Ouano

372 Beach or Maa Bay) and to the background concentrations generally considered for tropical

373 areas $\left(<1 \mu \mathrm{g} \mathrm{g}^{-1}\right.$ dry wt in mussels; Klumpp and Burdon-Jones, 1982) and temperate areas $(<$

$3746 \mu \mathrm{g} \mathrm{g}^{-1}$ dry wt in clams and oysters; Cohen et al., 2001). Various bivalves are able to

375 accumulate $\mathrm{Ag}$ up to very high concentrations by trapping it as $\mathrm{Ag}_{2} \mathrm{~S}$, a stable and non-toxic

376 compound (eg, Berthet et al., 1992; Bustamante and Miramand, 2005). The occurrence of a

377 similar detoxification mechanism in G. tumidum and I. isognomon could explain the high Ag

378 concentrations observed in their soft tissues. Natural sources of Ag are quite rare in the 
environment (Luoma et al., 1995) and Ag is considered as a reliable proxy of anthropogenic

380 input $\mathrm{s}$ in coastal waters, such as sewage sludge and boating activities, (Martin et al., 1988;

381 Sanudo-Willhelmy and Flegal, 1992). Therefore the enrichment of Ag in bivalves from

382 Grande Rade would be most probably related to this kind of domestic inputs.

383

384

385

386

387

388

389

390

391

392

393

394

395

\section{Conclusions}

In New Caledonia, contaminants released in the lagoon are clearly a matter of concern, as reflected by the elevated concentrations in some elements found in the marine organisms investigated in the present work. The two bivalve species considered in this study merit consideration as they appear to be bioindicator species of interest for surveying the contamination status of the New Caledonian waters. Indeed, these species (1) are abundant and widely distributed in New Caledonia (as well as in other tropical areas), (2) show elevated bioaccumulation capacity, and (3) are able to reveal the differences in element concentrations among different areas, even in complex environments (the locations examined here were subjected to various contamination sources).

In a future biomonitoring programme in the SW lagoon of New Caledonia, element concentrations in organisms from Ouano Beach and Maa Bay could be considered as background concentrations for all elements, except for As and Zn. Furthermore, due to the very high levels of As measured in clams from Ouano Beach, the speciation of As in clam tissues should be determined in detail (particularly their inorganic As content) to assess whether their consumption could represent a potential hazard for local consumers (Warnau et al., 2007; Metian et al., 2008).

\section{Acknowledgements}

Authors thank M. Robert (CCA, Univ. La Rochelle) for his analytical advices. LH was beneficiary of a CIFRE scholarship (ANRT, France) supported by the Goro-Nickel Company, 
404 New Caledonia. MW is an Honorary Senior Research Associate of the National Fund for

405 Scientific Research (NFSR, Belgium). This work was supported by the IAEA, the French

406 PNEC Programme, the IRD and LIENSs. The IAEA is grateful for the support provided to its

407 Marine Environment Laboratories by the Government of the Principality of Monaco.

408

\section{References}

410 Benson, A.A., Summons, R.B., 1981. Arsenic accumulation in Great Barrier reef 411 invertebrates. Science 211, 482-483.

412 Berthet, B., Amiard, J.C., Amiard-Triquet, C., Martoja, R., Jeantet, A.Y., 1992.

413 Bioaccumulation toxicity and physico-chemical speciation of silver in bivalve molluscs:

414 ecotoxicological and health consequences. Sci. Total Environ. 125, 97-122.

415 Boyden, C.R., 1977. Effect of size upon metal content of shellfish. J. Mar. Biol. Assoc. U. K. $416 \quad 57,675-714$.

417 Breau, L. 2003. Etude de la bioaccumulation des métaux dans quelques espèces marines 418 tropicales: recherche de bioindicateurs de contamination et application à la surveillance de 419 l'environnement côtier dans le lagon sud-ouest de la Nouvelle-Calédonie. Ph.D. Thesis, $420 \quad$ Université de La Rochelle, France.

421 Brown, B.E., Holley, M.C., 1982. Metal levels associated with tin dredging and smelting and 422 their effect upon interdital reef flats at Ko Phuket, Thailand. Coral Reefs 1, 131-137.

423 Bustamante, P., Grigioni, S., Boucher-Rodoni, R., Caurant, F., Miramand, P., 2000. 424 Bioaccumulation of 12 trace elements in the tissues of the Nautilus macromphalus from 425 New Caledonia. Mar. Pollut. Bull. 40, 688-696.

426 Bustamante, P., Miramand, P., 2005. Subcellular and body distributions of 17 trace elements 427 in the variegated scallop Chlamys varia from the French coast of the Bay of Biscay. Sci. 428 Total Environ. 337, 59-73. 
Campos, N.H., 1988. Selected bivalves for monitoring of heavy metal contamination in the 430 Colombian Caribbean. In: Seeliger, U., De Lacerda, L.D., Patchineelam, S.R. (Eds), Metals in coastal environments of Latin America. Springer-Verlag, pp. 270-275.

Cheung, Y.H., Wong, M.H., 1997. Depuration and bioaccumulation of heavy metals by clams from Tolo Harbour, Hong Kong. Toxicol. Environ. Chem. 58, 103-116.

Cohen, T., Que Hee, S.S., Ambrose, R.F., 2001. Trace metals in fish and invertebrates of three California coastal wetlands. Mar. Pollut. Bull. 42, 224-232.

Corrêa Junior, J.D., Allodi, S., Amado Filho, G.M., Farina, M., 2000. Zn accumulation in phosphate granules of Ucides cordatus hepatopancreas. Braz. J. Med. Biol. Res. 33, $217-$

Coteur, G., Gosselin, P., Wantier, P., Chambost-Manciet, Y., Danis, B., Pernet, P., Warnau, M., Dubois, P., 2003. Echinoderms as bioindicators, bioassays, and impact assessment tools of sediment-associated metals and PCBs in the North Sea. Archives of Environ. Contam. Toxicol. 45, 190-202.

Dalto, A.G., Grémare, A., Dinet, A., Fichet, D., 2006. Muddy-bottom meiofauna responses to metal concentrations and organic enrichment in New Caledonia South-West Lagoon. Estuar. Coast. Shelf Sci. 64, 629-644.

de Mora, S., Fowler, S.W., Wyse, E., Azemard, S., 2004. Distribution of heavy metals in marine bivalves, fish and coastal sediments in the Gulf of Oman. Mar. Pollut. Bull. 49, 410-424.

Dougherty, G., 1988. Heavy metal concentrations in bivalves from Fiji's coastal waters. Mar.

451 Eisler, R., 1981. Trace metal concentrations in marine organisms. Pergamon Press, New 452 York. 
Fattorini, D., Alonso Hernandez, C.M., Diaz Asencio, M., Munoz Caravaca, A., Pannacciulli,

454 F., Tangherlini, M., Regoli, F., 2004. Chemical speciation of arsenic in different marine 455 organisms: importance in monitoring studies. Mar. Environ. Res. 58, 845-850.

456 Fattorini, D., Regoli, F., 2004. Arsenic speciation in tissues of the Mediterranean polychaete 457 Sabella spallanzanii. Environ. Toxicol. Chem. 23, 1881-1887.

458 Francesconi, K.A., Gailer, J., Edmonds, J.S., Goessler, W., Irgolic, K.J., 1999. Uptake of 459 arseno-betaines by the mussel Mytilus edulis. Comp. Biochem. Physiol. C Comp. $460 \quad$ Pharmacol. 122, 131-137.

461 Gibbs, P.E., Langston, W.J., Burt, G.R., Pascoe, P.L., 1983. Tharyx marioni (Polychaeta): a 462 remarkable accumulator of arsenic. J. Mar. Biol. Assoc. UK 63, 313-325.

463 Goldberg, E.D., Koide, M., Hodge, V., Flegal, A.R., Martin, J.H., 1983. U.S. Mussel Watch: 464 1977-1978 results on trace metals and radionuclides. Estuar. Coast. Shelf Sci. 16, 69-93.

465 Gómez-Batista, M., Metian, M., Teyssié, J.L., Alonso-Hernández, C., Warnau, M., 2007. 466 Bioaccumulation of dissolved arsenic in the oyster Crassostrea virginica: a radiotracer 467 study. Environ. Bioindic. 2, 237-244.

468 Goro-Nickel, 2001. Projet Goro Nickel. Evaluation environnementale.

469 Hédouin, L., 2006. Caractérisation d'espèces bioindicatrices pour la surveillance des activités 470 minières et la gestion de l'environnement en milieu récifal et lagonaire: application au 471 lagon de Nouvelle-Calédonie. Ph.D. Thesis, Université de La Rochelle, France.

472 Hédouin, L. Metian, M., Teyssié, J.L., Fichez, R., Warnau., M., submitted. Delineation of 473 heavy metal contamination pathways (seawater, food and sediment) in tropical oysters 474 from New Caledonia using radiotracer techniques. submitted to Mar. Pollut. Bull.

475 Hédouin, L., Metian, M., Teyssié, J.L., Fowler, S.W., Fichez, R., Warnau, M., 2006. 476 Allometric relationships in the bioconcentration of heavy metals by the edible tropical 477 clam Gafrarium tumidum. Sci. Total Environ. 366, 154-163. 
478 Hédouin, L., Pringault, O., Metian, M., Bustamante, P., Warnau, M., 2007. Nickel 479 bioaccumulation in bivalves from the New Caledonia lagoon: Seawater and food $480 \quad$ exposure. Chemosphere 66, 1449-1457.

481 Hung, T.-C., Meng, P.-J., Han, B.-C., Chuang, A., Huang, C.-C., 2001. Trace metals in 482 different species of mollusca, water and sediments from Taiwan coastal area. 483 Chemosphere 44, 833-841.

484 IMWC (International Mussel Watch Committee), 1995. International Mussel Watch Project 485 Initial Implementation Phase, Final Report. In: Farrington, J.W., Tripp, B.W. (Eds), 486 NOAA Technical Memorandum NOS ORCA 95. NOAA Office of Ocean Resources 487 Conservation and Assessment, Rockville, MD.

488 Jaffe, R., Leal, I., Alvarado, J., Gardinali, P.R., Sericano, J.L., 1998. Baseline study on the 489 levels of organic pollutants and heavy metals in bivalves from the Morrocoy National 490 park, Venezuela. Mar. Pollut. Bull. 36, 925-929.

491 Jones, G.B., 1992. The effects of Trichodesmium blooms on water quality in the Great Barrier 492 Reef Lagoon. In: Carpenter, E.J., Capone, D.G., Rueter, J.G. (Eds), Marine pelagic 493 cyanobacteria Trichodesmium and other diazotrophs. Kluwer Academic Press, Boston, pp. $494 \quad 273-287$.

495 Jones, G.B., Mercurio, P., Olivier, F., 2000. Zinc in fish, crabs, oysters, and mangrove flora 496 and fauna from Cleveland bay. Mar. Pollut. Bull. 41, 345-352.

497 Kaise, T., Fukui, S., 1992. The chemical form and acute toxicity of arsenic compounds in 498 marine organisms. Appl. Organomet. Chem. 6, 155-160.

499 Klumpp, D.W., Burdon-Jones, C., 1982. Investigations of the potential of bivalve molluscs as $500 \quad$ indicators of heavy metals in tropical marine waters. Aust. J. Mar. Freshw. Res. 33, 285$501 \quad 300$. 
Labrosse, P., Fichez, R., Farman, R., Adams, T., 2000. New Caledonia. In: Sheppard, C.R.C.

503 (Ed.), Seas at the Millenium: An environmental evaluation. Pergamon, Amsterdam, pp. $504 \quad 723-736$.

505 Langston, W.J., 1980. Arsenic in U.K. estuarine sediments and its availability to benthic 506 organisms. J. Mar. Biol. Assoc. U. K. 60, 869-881.

507 Lim, P.E., Lee, C.W., Din, Z., 1995. Accumulation of heavy metals by cultured oysters from 508 Merbok estuary, Malaysia. Mar. Pollut. Bull. 31, 420-423.

509 Luoma, S.N., Bo, Y.B., Bryan, G.W., 1995. Fate, bioavailability and toxicity of silver in $510 \quad$ estuarine environments. Mar. Pollut. Bull. 31, 44-54.

511 Martin, M., Stephenson, M.D., Smith, D.R., Gutierrez-Galindo, E.A., Flores Munoz, G., 512 1988. Use of silver in mussels as a tracer of domestic wastewater discharge. Mar. Pollut. $513 \quad$ Bull. 19, 512-520.

514 Metian, M., 2003. Bioaccumulation des métaux lourds chez 4 espèces marines du lagon de $515 \quad$ Nouvelle Calédonie: Caractérisation de leur potentiel bioindicateur pour le monitoring des 516 activités minières locales. Master Thesis, Université Libre de Bruxelles, Belgium.

517 Metian, M., Bustamante, P., Hédouin, L., Warnau, M., 2008. Accumulation of trace elements 518 in the tropical scallop Comptopallium radula from coral reefs in New Caledonia. Environ. $519 \quad$ Pollut. 152, 543-552.

520 Mihaylov, I., Krause, E., Colton, D.F., Okita, Y., Duterque, J.-P., Perraud, J.-J., 2000. The 521 development of a novel hydrometallurgical process for nickel and cobalt recovery from 522 Goro laterite ore. Canadian Mining Metallurgical Bull. 93, 124-130.

523 Monniot, F., Martoja, R., Monniot, C., 1994. Cellular sites of iron and nickel accumulation in 524 ascidians related to the naturally and anthropic enriched New Caledonian environment. $525 \quad$ Ann. Inst. Oceanogr. 70, 205-216. 
Moore, N.W., 1966. A pesticide monitoring system with special reference to the selection of indicator. J. Appl. Ecol. 3, 261-269.

O'Connor, T.P., 1989. A summary of data on tissue contamination from the first three years (1986-1988) of the Mussel Watch project. Technical Memorandum NOS OMA 49, National Oceanic and Atmospheric Admistration, USA, pp. 22.

Olivier, F., Ridd, M., Klumpp, D., 2002. The use of transplanted cultured tropical oysters (Saccostrea commercialis) to monitor Cd levels in North Queensland coastal waters (Australia). Mar. Pollut. Bull. 44, 1051-1062.

Phillips, D.J.H., 1990a. Arsenic in aquatic organisms: a review, emphasizing chemical speciation. Aquat. Toxicol. 16, 151-186.

Phillips, D.J.H., 1990b. Use of macroalgae and invertebrates as monitors of metal levels in estuaries and coastal waters. In: Furness, R.W., Rainbow, P.S. (eds.), Heavy metals in the marine environment. CRC Press, Boca Raton, pp. 81-99.

Phillips, D.J.H., 1991. Selected trace elements and the use of biomonitors in subtropical and tropical marine ecosystems. Rev. Environ. Contam. Toxicol. 120, 105-128.

Phillips, D.J.H., Rainbow, P.S., 1993. Biomonitoring of trace aquatic contaminants, London.

Rainbow, P.S., 1995. Biomonitoring of heavy metal availability in the marine environment. Mar. Pollut. Bull. 31, 183-192.

Ratte, H.T., 1999. Bioaccumulation and toxicity of silver compounds: a review. Environ. Toxicol. Chem. 18, 89-108.

RNO-Antilles, Réseau National d'Observation de la Qualité du Milieu Marin-Antilles. Ifremer et Ministère de l'Ecologie et du Développement Durable, unpublished work.

Saed, K., Ismail, A., Omar, H., Kusnan, M., 2001. Accumulation of heavy metals ( $\mathrm{Zn}, \mathrm{Cu}, \mathrm{Pb}$, Cd) in flat-tree oysters Isognomon alatus exposed to pig farm effluent. Toxicol. Environ. Chem. 82, 45-58. 
551 Salomons, W., de Rooij, N.M., Derdijk, H., Bril, J., 1987. Sediments as a source for 552 contaminants? Hydrobiologia 149, 13-30.

553 Sanders, J.G., Osman, R.W., Riedel, G.F., 1989. Pathways of arsenic uptake and 554 incorporation in estuarine phytoplankton and the filter-feeding invertebrates Eurytemora 555 affinis, Balanus improvisus and Crassostrea virginica. Mar. Biol. 103, 319-325.

556 Sañudo-Willhelmy, S., Flegal, R., 1992. Anthropogenic silver in the Southern California 557 Bight: a new tracer of sewage in coastal waters. Environ. Sci. Technol. 26, 2147-2151.

558 Sbriz, L., Aquino, M.R., Alberto de Rodriguez, N.M., Fowler, S.W., Sericano, J.L., 1998.

559 Levels of chlorinated hydrocarbons and trace metals in bivalves and nearshore sediments 560 from the Dominican Republic. Mar. Pollut. Bull. 36, 971-979.

561 Szefer, P., Geldon, J., Ali, A.A., Paez-Osuna, F., Ruiz-Fernandes, A.C., Galvan, S.R.G., 562 1998. Distribution and association of trace metals in soft tissue and byssus of Mytella 563 strigata and other benthal organisms from Mazatlan harbour, mangrove lagoon of the 564 northwest coast of Mexico. Environ. Int. 24, 359-374.

565 Ünlü, M.Y., Fowler, S.W., 1979. Factors affecting the flux of arsenic through the mussel 566 Mytilus galloprovincialis. Mar. Biol. 51, 209-219.

567 UNU, 1994. Report of the UNU-IOC Workshop on Asia/Pacific Mussel Watch: Monitoring, 568 Research and Training United Nations University, 18-21 November 1994, Bali, Indonesia 569 Valette-Silver, N.J., Riedel, G.F., Crecelius, E.A., Windom, H., Smith, R.G., Dolvin, S.S., 570 1999. Elevated arsenic concentrations in bivalves from the southeast coasts of the USA. $571 \quad$ Mar. Environ. Res. 48, 311-333.

572 Vallee, B.L., Falchuk, K.H., 1993. The biochemical basis of zinc physiology. Physiol. Rev. $573 \quad 73,79-118$.

574 Warnau, M., Biondo, R., Temara, A., Bouquegneau, J.M., Jangoux, M., Dubois, P., 1998. 575 Distribution of heavy metals in the echinoid Paracentrotus lividus (Lmk) from the 
Mediterranean Posidonia oceanica ecosystem: seasonal and geographical variations. J.

$577 \quad$ Sea Res. 39, 267-280.

578 Warnau, M., Fowler, S.W., Teyssié, J.L., 1999. Biokinetics of radiocobalt in the asteroid 579 Asterias rubens (Echinodermata): sea water and food exposures. Mar. Pollut. Bull. 39: 159-164.

581 Warnau, M., Gómez-Batista, M., Alonso-Hernández, C., Regoli, F., 2007. Arsenic: Is it worth 582 monitoring in the Mediterranean Sea? In: Marine Sciences and Public Health - Some 583 Major Issues. CIESM Workshop Monographs n³1, Monaco, pp. 83-86.

584 Warnau, M., Iaccarino, M., De Biase, A., Temara, A., Jangoux, M., Dubois, P., Pagano, G., 585 1996a. Spermiotoxicity and embryotoxicity of heavy metals in the echinoid Paracentrotus $586 \quad$ lividus. Environ. Toxicol. Chem. 15, 1931-1936.

587 Warnau, M., Ledent, G., Temara, A., Alva, V., Jangoux, M., Dubois, P., 1995. Allometry of 588 heavy metal bioconcentration in the echinoid Paracentrotus lividus (Echinodermata). 589 Arch. Environ. Contam. Toxicol. 29, 393-399.

590 Warnau, M., Teyssié, J.L., Fowler, S.W., 1996b. Biokinetics of selected heavy metals and 591 radionuclides in the common Mediterranean echinoid Paracentrotus lividus: seawater and 592 food exposure. Mar. Ecol. Prog. Ser. 141, 83-94.

593 Zar, J.H., 1996. Biostatistical analysis. Upper Saddle River, New Jersey.

594 Zingde, M.D., Singbal, S.Y.S., Moraes, C.F., Reddy, C.V.G., 1976). Arsenic, copper, zinc 595 and manganese in the marine flora and fauna of coastal and estuarine waters around Goa. 596 Ind. J. Mar. Sci. 5, 212-217. 
599 Caption to Figures

600

601

602 Figure 1. Map of the sampling sites along the SW coast of New Caledonia (Ouano Beach is 603 not represented on the map).

604

605

606 Figure 2. Comparisons of element concentrations in bivalves, using multiple comparison test

607 of Tukey performed after 2-way ANOVA in (A) the oyster Isognomon isognomon and (B) the 608 clam Gafrarium tumidum.

609 Mean concentrations are ranked from the left to the right by decreasing order. Concentrations

610 in underlined body compartments or locations are not significantly different $(\alpha=0.05)$.

611 Body compartments: DG (digestive gland), G (gills), M (adductor muscle), VM (visceral 612 mass) and R (remaining soft parts).

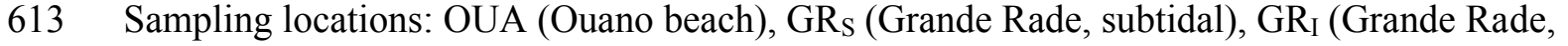
614 intertidal), DUM (Dumbéa Bay), and KOU (Koutio Bay).

615 


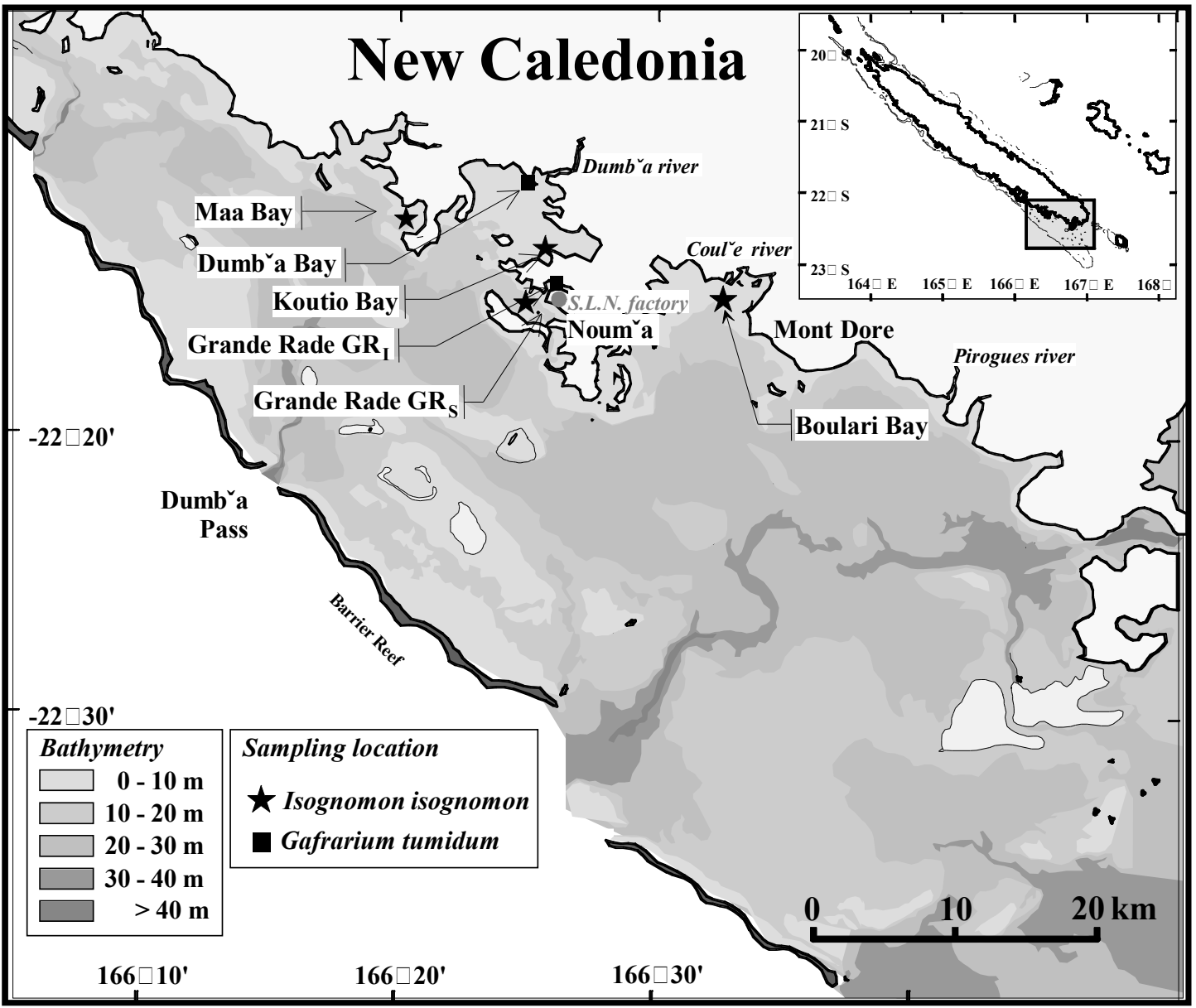

Figure 1. 


\section{A- Isognomon isognomon}

A-1: Body compartment variation

\begin{tabular}{|c|c|c|c|c|}
\hline Metal & \multicolumn{4}{|c|}{ Compartment ranking } \\
\hline Ag & G & VM & $\mathrm{R}$ & $\mathrm{M}$ \\
\hline As & M & G & VM & $\mathrm{R}$ \\
\hline Cd & $\mathrm{R}$ & G & VM & M \\
\hline Co & VM & G & $\mathrm{R}$ & M \\
\hline $\mathrm{Cr}$ & VM & G & $\mathrm{R}$ & M \\
\hline $\mathbf{C u}$ & VM & G & $\mathrm{R}$ & M \\
\hline Mn & $\mathrm{R}$ & VM & G & M \\
\hline $\mathbf{N i}$ & G & VM & $\mathrm{R}$ & M \\
\hline Zn & G & $\mathrm{R}$ & VM & M \\
\hline
\end{tabular}

\section{B- Gafrarium tumidum}

B-1: Body compartment variation

\begin{tabular}{|c|c|c|c|}
\hline Metal & \multicolumn{3}{|c|}{ Compartment ranking } \\
\hline $\mathbf{A g}$ & $\bar{G}$ & $\overline{\mathrm{DG}}$ & $\mathrm{R}$ \\
\hline As & DG & $\mathrm{G}$ & $\mathrm{R}$ \\
\hline Cd & DG & $\mathrm{R}$ & G \\
\hline Co & G & DG & $\mathrm{R}$ \\
\hline $\mathrm{Cr}$ & DG & $\mathrm{G}$ & $\mathrm{R}$ \\
\hline $\mathrm{Cu}$ & DG & $\mathrm{G}$ & $\mathrm{R}$ \\
\hline Mn & DG & $\mathrm{R}$ & G \\
\hline $\mathbf{N i}$ & DG & $\mathrm{G}$ & $\mathrm{R}$ \\
\hline Zn & DG & $\mathrm{G}$ & $\mathrm{R}$ \\
\hline
\end{tabular}

\begin{tabular}{|c|c|c|c|c|}
\hline Metal & \multicolumn{4}{|c|}{ Location ranking } \\
\hline $\mathbf{A g}$ & $\mathrm{GR}_{\mathrm{S}}$ & $\mathrm{KOU}$ & $\mathrm{BOU}$ & MAA \\
\hline As & MAA & $\mathrm{BOU}$ & $\mathrm{GR}_{\mathrm{S}}$ & $\mathrm{KOU}$ \\
\hline Cd & MAA & $\mathrm{KOU}$ & $\mathrm{BOU}$ & $\mathrm{GR}_{\mathrm{S}}$ \\
\hline Co & $\mathrm{BOU}$ & $\mathrm{GR}_{\mathrm{S}}$ & $\mathrm{KOU}$ & MAA \\
\hline $\mathrm{Cr}$ & KOU & $\mathrm{BOU}$ & MAA & $\mathrm{GR}_{\mathrm{S}}$ \\
\hline $\mathrm{Cu}$ & $\mathrm{GR}_{\mathrm{S}}$ & $\mathrm{BOU}$ & MAA & $\mathrm{KOU}$ \\
\hline Mn & $\mathrm{GR}_{\mathrm{S}}$ & $\mathrm{BOU}$ & MAA & $\mathrm{KOU}$ \\
\hline $\mathbf{N i}$ & $\mathrm{BOU}$ & $\mathrm{GR}_{\mathrm{S}}$ & $\mathrm{KOU}$ & MAA \\
\hline $\mathbf{Z n}$ & MAA & $\mathrm{GR}_{\mathrm{S}}$ & $\mathrm{KOU}$ & BOU \\
\hline
\end{tabular}

B-2: Geographical variation

\begin{tabular}{|c|c|c|c|}
\hline Metal & \multicolumn{3}{|c|}{ Location ranking } \\
\hline Ag & $\mathrm{GR}_{\mathrm{I}}$ & DUM & OUA \\
\hline As & OUA & $\mathrm{GR}_{\mathrm{I}}$ & DUM \\
\hline Cd & $\mathrm{GR}_{\mathrm{I}}$ & OUA & DUM \\
\hline Co & DUM & $\mathrm{GR}_{\mathrm{I}}$ & OUA \\
\hline $\mathrm{Cr}$ & $\mathrm{GR}_{\mathrm{I}}$ & DUM & OUA \\
\hline $\mathrm{Cu}$ & $\mathrm{GR}_{\mathrm{I}}$ & DUM & OUA \\
\hline Mn & $\mathrm{GR}_{\mathrm{I}}$ & DUM & OUA \\
\hline $\mathbf{N i}$ & $\mathrm{GR}_{\mathrm{I}}$ & DUM & OUA \\
\hline Zn & $\mathrm{GR}_{\mathrm{I}}$ & DUM & OUA \\
\hline
\end{tabular}

Figure 2. 
Table 1. Element concentrations in sediment (mean $\pm \mathrm{SD} ; \mu \mathrm{g} \mathrm{g}^{-1}$ dry $\mathrm{wt}, \mathrm{n}=3$ ).

\begin{tabular}{|c|c|c|c|c|c|c|c|c|c|}
\hline Sampling stations & $\overline{A g}$ & As & $\mathbf{C d}$ & Co & $\mathrm{Cr}$ & $\mathrm{Cu}$ & Mn & $\mathbf{N i}$ & $\mathbf{Z n}$ \\
\hline \multicolumn{10}{|c|}{ Sediment } \\
\hline Ouano Beach $^{1}$ & $<0.1^{*}$ & $2.9 \pm 1.2^{\mathrm{a}}$ & $<0.3^{*}$ & $0.8 \pm 0.4^{\mathrm{a}}$ & $7.2 \pm 2.7^{\mathrm{a}}$ & $0.5 \pm 1.0^{\mathrm{a}}$ & $41.7 \pm 15.7^{\mathrm{a}}$ & $5.1 \pm 3.2^{\mathrm{a}}$ & $3.3 \pm 1.9^{\mathrm{a}}$ \\
\hline Grande Rade $\mathbf{G R}_{\mathbf{I}}{ }^{1}$ & $0.4 \pm 0.1$ & $8.5 \pm 1.6^{\mathrm{b}}$ & $2.4 \pm 0.3$ & $46.2 \pm 9.1^{b}$ & $292 \pm 56^{\mathrm{b}}$ & $26.9 \pm 8.8^{b}$ & $288 \pm 40^{b}$ & $797 \pm 149^{b}$ & $141 \pm 18^{b}$ \\
\hline Maa Bay $^{2}$ & $<0.1^{*}$ & $6.4 \pm 0.3^{\mathrm{a}}$ & $1.0 \pm 0.2^{b}$ & $4.6 \pm 2.3^{\mathrm{ab}}$ & $44.1 \pm 7.9^{\mathrm{a}}$ & $10.7 \pm 3.5^{\mathrm{b}}$ & $132 \pm 7.8^{b}$ & $64.2 \pm 13.5^{\mathrm{a}}$ & $15.2 \pm 3.1^{\mathrm{a}}$ \\
\hline Koutio Bay $^{2}$ & $<0.1^{*}$ & $9.9 \pm 0.7^{b}$ & $0.5 \pm 0.01^{\mathrm{a}}$ & $6.2 \pm 1.1^{b}$ & $38.6 \pm 2.7^{\mathrm{a}}$ & $1.1 \pm 0.3^{\mathrm{a}}$ & $81.6 \pm 3.5^{\mathrm{a}}$ & $82.0 \pm 5.1^{\mathrm{a}}$ & $9.4 \pm 0.6^{\mathrm{a}}$ \\
\hline Boulari Bay $^{2}$ & $<0.1^{*}$ & $46.9 \pm 1.5^{\mathrm{c}}$ & $5.1 \pm 0.5^{\mathrm{c}}$ & $61.2 \pm 16.2^{\mathrm{c}}$ & $662 \pm 50^{\mathrm{b}}$ & $4.6 \pm 1.6^{\mathrm{b}}$ & $565 \pm 15^{c}$ & $900 \pm 78^{c}$ & $33.1 \pm 3.4^{\mathrm{b}}$ \\
\hline
\end{tabular}

* Concentrations $<$ detection limit.

${ }^{1,2}$ stations where clams and oysters were collected, respectively.

Significant differences among the mean concentrations in sediments from the different sampling stations are indicated by superscripts; means sharing the same superscript $\left({ }^{\mathrm{a}, \mathrm{b}, \mathrm{c}}\right)$ are not significantly different among sampling stations $\left(\mathrm{p}_{\text {Tukey }}>0.05\right)$.

Comparisons among sediment concentrations were carried out separately among the stations where clams or oysters were collected. 
Table 2. Element concentrations in the oyster Isognomon isognomon (mean $\pm \mathrm{SD} ; \mu \mathrm{g} \mathrm{g}^{-1}$ dry wt, $\mathrm{n}=6$ ).

Body compartments: VM (visceral mass), M (adductor muscle), G (gills), R (remaining soft parts), WSP (whole-soft parts; reconstructed values).

\begin{tabular}{|c|c|c|c|c|c|c|c|c|c|c|}
\hline Compartments & \% weight & Ag & As & Cd & Co & $\mathrm{Cr}$ & $\mathrm{Cu}$ & Mn & $\mathbf{N i}$ & Zn \\
\hline \multicolumn{11}{|c|}{ Koutio Bay } \\
\hline VM & $51 \pm 12$ & $21.7 \pm 24.3$ & $21.7 \pm 5.2$ & $1.13 \pm 0.42$ & $1.05 \pm 0.65$ & $13.6 \pm 2.0$ & $3.0 \pm 2.2$ & $26.3 \pm 9.8$ & $4.6 \pm 3.4$ & $3,983 \pm 2,555$ \\
\hline M & $26 \pm 6$ & $2.4 \pm 2.1$ & $20.5 \pm 2.9$ & $1.23 \pm 0.56$ & $0.15 \pm 0.04$ & $2.2 \pm 1.7$ & $1.1 \pm 0.3$ & $4.4 \pm 1.7$ & $<1.0^{*}$ & $1,356 \pm 876$ \\
\hline $\mathrm{G}$ & $6 \pm 2$ & $52.7 \pm 23.5$ & $24.2 \pm 6.6$ & $1.47 \pm 0.63$ & $1.04 \pm 0.35$ & $7.1 \pm 2.0$ & $8.7 \pm 2.7$ & $8.8 \pm 3.6$ & $6.9 \pm 2.4$ & $11,357 \pm 5,953$ \\
\hline $\mathrm{R}$ & $17 \pm 5$ & $9.6 \pm 10.7$ & $25.2 \pm 5.8$ & $1.59 \pm 0.74$ & $0.62 \pm 0.34$ & $5.9 \pm 1.6$ & $5.7 \pm 3.2$ & $30.3 \pm 25.3$ & $5.1 \pm 1.5$ & $6,346 \pm 4,224$ \\
\hline WSP & & $14.5 \pm 7.1^{\mathrm{a}}$ & $21.6 \pm 2.4^{\mathrm{a}}$ & $1.23 \pm 0.40^{\mathrm{a}}$ & $0.69 \pm 0.20^{\mathrm{a}}$ & $9.0 \pm 1.6^{\mathrm{c}}$ & $3.1 \pm 0.9^{\mathrm{a}}$ & $20.4 \pm 8.3^{\mathrm{a}}$ & $3.6 \pm 1.1^{\mathrm{a}}$ & $3,832 \pm 1,529^{b}$ \\
\hline \multicolumn{11}{|c|}{ Maa Bay } \\
\hline VM & $51 \pm 4$ & $2.04 \pm 1.81$ & $64.3 \pm 9.9$ & $1.97 \pm 1.04$ & $0.58 \pm 0.26$ & $3.1 \pm 0.8$ & $10.6 \pm 1.6$ & $17.1 \pm 6.4$ & $2.2 \pm 1.1$ & $11,333 \pm 5,904$ \\
\hline $\mathrm{M}$ & $25 \pm 1$ & $0.12 \pm 0.08$ & $106 \pm 13$ & $0.81 \pm 0.50$ & $0.03 \pm 0.03$ & $2.7 \pm 0.1$ & $0.4 \pm 0.3$ & $4.7 \pm 3.9$ & $<0.2^{*}$ & $5,781 \pm 3,299$ \\
\hline $\mathrm{G}$ & $4 \pm 2$ & $0.58 \pm 0.31$ & $91.5 \pm 20.6$ & $3.66 \pm 1.79$ & $0.53 \pm 0.14$ & $4.8 \pm 0.2$ & $14.0 \pm 5.0$ & $13.0 \pm 5.3$ & $3.8 \pm 0.8$ & $41,790 \pm 14,629$ \\
\hline $\mathrm{R}$ & $20 \pm 7$ & $0.12 \pm 0.08$ & $57.9 \pm 9.5$ & $3.01 \pm 2.81$ & $0.50 \pm 0.001$ & $4.5 \pm 0.6$ & $6.6 \pm 0.7$ & $55.3 \pm 29.6$ & $4.0 \pm 0.3$ & $17,694 \pm 8,103$ \\
\hline WSP & & $1.47 \pm 1.09^{b}$ & $76.6 \pm 9.3^{b}$ & $1.80 \pm 1.4^{\mathrm{a}}$ & $0.45 \pm 0.16^{\mathrm{a}}$ & $3.5 \pm 0.5^{\mathrm{ab}}$ & $6.8 \pm 0.5^{\mathrm{ab}}$ & $22.3 \pm 14.6^{\mathrm{a}}$ & $2.2 \pm 0.5^{\mathrm{a}}$ & $13,817 \pm 6,621^{\mathrm{a}}$ \\
\hline \multicolumn{11}{|c|}{ Grande Rade $\left(\mathbf{G R}_{\mathbf{S}}\right)$} \\
\hline $\mathrm{VM}$ & $28 \pm 2$ & $37.1 \pm 9.6$ & $39.5 \pm 4.5$ & $1.21 \pm 0.69$ & $1.38 \pm 0.25$ & $3.8 \pm 0.5$ & $44.6 \pm 17.3$ & $42.8 \pm 9.6$ & $8.8 \pm 2.0$ & $8,188 \pm 2,757$ \\
\hline M & $25 \pm 3$ & $3.7 \pm 2.8$ & $46.0 \pm 4.9$ & $0.81 \pm 0.19$ & $0.13 \pm 0.04$ & $0.6 \pm 0.1$ & $1.6 \pm 0.3$ & $5.0 \pm 2.7$ & $<0.6^{*}$ & $1,958 \pm 443$ \\
\hline $\mathrm{G}$ & $7 \pm 2$ & $217 \pm 83$ & $42.4 \pm 8.8$ & $0.93 \pm 0.28$ & $1.37 \pm 0.44$ & $6.3 \pm 1.2$ & $13.5 \pm 3.5$ & $8.7 \pm 3.6$ & $8.3 \pm 2.7$ & $14,360 \pm 3,503$ \\
\hline $\mathrm{R}$ & $40 \pm 3$ & $18.3 \pm 7.0$ & $31.7 \pm 4.1$ & $1.46 \pm 0.59$ & $0.40 \pm 0.14$ & $2.5 \pm 0.6$ & $8.8 \pm 2.7$ & $52.0 \pm 21.1$ & $3.1 \pm 0.5$ & $10,233 \pm 3,724$ \\
\hline WSP & & $32.8 \pm 6.5^{\mathrm{c}}$ & $38.2 \pm 4.3^{c}$ & $1.18 \pm 0.44^{\mathrm{a}}$ & $0.67 \pm 0.09^{b}$ & $2.7 \pm 0.3^{\mathrm{b}}$ & $17.3 \pm 5.3^{\mathrm{c}}$ & $34.7 \pm 11.5^{\mathrm{a}}$ & $4.4 \pm 0.8^{\mathrm{a}}$ & $7,873 \pm 2,087^{\mathrm{a}}$ \\
\hline \multicolumn{11}{|c|}{ Boulari Bay } \\
\hline VM & $28 \pm 6$ & $49.4 \pm 8.4$ & $59.2 \pm 19.2$ & $1.48 \pm 0.88$ & $3.29 \pm 1.99$ & $7.6 \pm 2.9$ & $24.8 \pm 12.8$ & $38.8 \pm 21.8$ & $26.0 \pm 7.9$ & $1,741 \pm 2,175$ \\
\hline M & $21 \pm 3$ & $0.2 \pm 0.2$ & $56.5 \pm 13.1$ & $0.84 \pm 0.37$ & $0.24 \pm 0.10$ & $4.2 \pm 0.5$ & $1.0 \pm 0.1$ & $3.5 \pm 1.4$ & $1.7 \pm 1.0$ & $279 \pm 94$ \\
\hline G & $8 \pm 2$ & $9.0 \pm 5.9$ & $51.2 \pm 9.1$ & $0.96 \pm 0.50$ & $2.56 \pm 0.48$ & $5.3 \pm 1.4$ & $7.0 \pm 0.6$ & $9.3 \pm 3.7$ & $29.8 \pm 5.1$ & $4,437 \pm 1,880$ \\
\hline $\mathrm{R}$ & $43 \pm 3$ & $4.3 \pm 3.1$ & $45.9 \pm 9.6$ & $1.43 \pm 0.78$ & $1.18 \pm 0.41$ & $5.5 \pm 5.1$ & $6.3 \pm 1.1$ & $41.8 \pm 21.9$ & $14.5 \pm 5.2$ & $2,017 \pm 1,427$ \\
\hline WSP & & $16.5 \pm 4.0^{\mathrm{a}}$ & $51.7 \pm 10.8^{\mathrm{d}}$ & $1.28 \pm 0.68^{\mathrm{a}}$ & $1.60 \pm 0.49^{\mathrm{a}}$ & $5.7 \pm 2.9^{\mathrm{a}}$ & $9.8 \pm 2.1^{\mathrm{a}}$ & $30.8 \pm 16.0^{\mathrm{a}}$ & $16.0 \pm 3.7^{b}$ & $1,718 \pm 1,290^{b}$ \\
\hline
\end{tabular}

* Concentration $<$ detection limit.

Differences among the concentrations in WSP from the four locations are indicated by superscripts; means sharing the same superscript are not significantly different among sampling stations $\left(\mathrm{p}_{\text {Tukey }}>0.05\right)$ 
Table 3. Variability (\%) in element concentrations measured in the oyster Isognomon isognomon and the clam Gafrarium tumidum explained by the factors considered (body compartment and sampling location) and their interaction

\begin{tabular}{rccccccccc}
\hline \multicolumn{1}{c}{ Factors } & \multicolumn{7}{c}{ Explained Variability (\%) } \\
& Ag & As & Cd & Co & Cr & Cu & Mn & Ni & Zn \\
\hline I. isognomon & & & & & & & & & \\
Body compartment & 20.1 & 6.6 & 12.6 & 27.1 & 19.6 & 28.8 & 49.2 & 19.6 & 35.5 \\
Location & 19.1 & 69.9 & 16.0 & 26.0 & 23.6 & 17.2 & 3.9 & 47.9 & 29.0 \\
Compartment $\times$ location & 43.6 & 8.9 & 14.0 & 14.3 & 28.2 & 34.6 & 7.2 & 20.8 & 17.2 \\
Residual & 17.1 & 14.7 & 57.5 & 32.6 & 28.6 & 19.3 & 39.7 & 11.7 & 18.4 \\
& & & & & & & & & \\
G. tumidum & & & & & & & & & \\
Body compartment & 6.2 & 3.2 & 13.2 & 16.9 & 9.3 & 14.2 & 9.1 & 10.6 & 14.9 \\
Location & 39.1 & 84.1 & 30.1 & 23.1 & 38.6 & 61.6 & 22.5 & 39.4 & 13.3 \\
Residual & 41.1 & 9.2 & 47.1 & 40.7 & 35.3 & 9.8 & 43.9 & 35.0 & 60.6 \\
\hline
\end{tabular}


Table 4. Element concentrations in the clam Gafrarium tumidum (mean $\pm \mathrm{SD} ; \mu \mathrm{g} \mathrm{g}{ }^{-1}$ dry wt, $\mathrm{n}=6$ ).

Body compartments: DG (digestive gland), G (gills), R (remaining soft parts), WSP (whole-soft parts; reconstructed values).

\begin{tabular}{|c|c|c|c|c|c|c|c|c|c|c|}
\hline Compartments & \% weight & Ag & As & Cd & Co & $\mathrm{Cr}$ & $\mathrm{Cu}$ & Mn & $\mathbf{N i}$ & $\mathbf{Z n}$ \\
\hline \multicolumn{11}{|c|}{ Dumbéa Bay } \\
\hline$\overline{D G}$ & $14 \pm 4$ & $4.6 \pm 6.0$ & $70.3 \pm 34.3$ & $0.21 \pm 0.11$ & $4.6 \pm 1.8$ & $8.4 \pm 4.3$ & $22.0 \pm 9.0$ & $14.5 \pm 9.9$ & $33.9 \pm 14.2$ & $105 \pm 42$ \\
\hline G & $12 \pm 3$ & $0.49 \pm 0.55$ & $39.6 \pm 13.1$ & $0.20 \pm 0.11$ & $4.5 \pm 2.0$ & $2.5 \pm 1.3$ & $7.4 \pm 3.0$ & $25.2 \pm 26.3$ & $37.9 \pm 13.5$ & $76.7 \pm 24.1$ \\
\hline $\mathrm{R}$ & $75 \pm 3$ & $1.1 \pm 0.9$ & $32.8 \pm 8.1$ & $0.16 \pm 0.02$ & $3.6 \pm 0.7$ & $4.6 \pm 1.6$ & $5.9 \pm 1.1$ & $34.0 \pm 36.5$ & $29.0 \pm 6.8$ & $55.2 \pm 9.8$ \\
\hline WSP & & $1.4 \pm 1.1^{\mathrm{a}}$ & $37.4 \pm 7.4^{\mathrm{a}}$ & $0.17 \pm 0.03^{\mathrm{a}}$ & $3.8 \pm 0.7^{\mathrm{a}}$ & $4.8 \pm 1.3^{\mathrm{a}}$ & $7.9 \pm 1.3^{\mathrm{a}}$ & $35.9 \pm 43.5^{\mathrm{a}}$ & $30.2 \pm 6.0^{\mathrm{a}}$ & $62.7 \pm 10.2^{\mathrm{a}}$ \\
\hline \multicolumn{11}{|c|}{ Ouano Beach } \\
\hline $\mathrm{DG}$ & $14 \pm 3$ & $<1.4^{*}$ & $606 \pm 135$ & $0.33 \pm 0.04$ & $1.8 \pm 0.2$ & $3.5 \pm 1.1$ & $14.6 \pm 2.7$ & $5.0 \pm 2.5$ & $9.2 \pm 1.7$ & $78.3 \pm 10.4$ \\
\hline G & $11 \pm 3$ & $<0.01^{*}$ & $516 \pm 117$ & $0.19 \pm 0.09$ & $1.8 \pm 0.5$ & $1.9 \pm 1.5$ & $6.4 \pm 2.2$ & $7.9 \pm 2.9$ & $14.1 \pm 4.4$ & $89.7 \pm 27.9$ \\
\hline $\mathrm{R}$ & $76 \pm 5$ & $<0.02 *$ & $360 \pm 121$ & $0.16 \pm 0.06$ & $1.0 \pm 0.3$ & $3.1 \pm 2.8$ & $4.4 \pm 1.1$ & $5.9 \pm 1.6$ & $7.1 \pm 1.5$ & $50.7 \pm 8.2$ \\
\hline WSP & & $<0.02^{* \mathrm{a}}$ & $441 \pm 84^{b}$ & $0.19 \pm 0.04^{\mathrm{a}}$ & $1.1 \pm 0.2^{b}$ & $3.2 \pm 2.2^{\mathrm{a}}$ & $5.6 \pm 1.0^{\mathrm{a}}$ & $5.5 \pm 1.5^{\mathrm{a}}$ & $8.1 \pm 1.5^{b}$ & $55.6 \pm 7.8^{\mathrm{a}}$ \\
\hline \multicolumn{11}{|c|}{ Grande Rade $\left(G_{\mathbf{I}}\right)$} \\
\hline DG & $29 \pm 6$ & $51.5 \pm 33.6$ & $67.9 \pm 14.6$ & $1.30 \pm 0.88$ & $2.4 \pm 1.4$ & $10.7 \pm .4$ & $146 \pm 37$ & $324 \pm 260$ & $91.7 \pm 45.8$ & $282 \pm 276$ \\
\hline G & $12 \pm 2$ & $89.4 \pm 75.6$ & $63.2 \pm 18.5$ & $0.21 \pm 0.09$ & $5.6 \pm 3.6$ & $12.1 \pm 3.4$ & $119 \pm 40$ & $27.9 \pm 20.3$ & $49.0 \pm 32.0$ & $123 \pm 65$ \\
\hline $\mathrm{R}$ & $59 \pm 7$ & $16.3 \pm 10.8$ & $47.1 \pm 16.2$ & $0.52 \pm 0.46$ & $1.5 \pm 1.0$ & $5.8 \pm 1.8$ & $34.3 \pm 17.5$ & $93.4 \pm 86.2$ & $29.7 \pm 9.6$ & $74.5 \pm 12.7$ \\
\hline WSP & & $33.1 \pm 13.4^{b}$ & $55.0 \pm 15.1^{\mathrm{a}}$ & $0.74 \pm 0.25^{b}$ & $2.2 \pm 1.0^{\mathrm{c}}$ & $8.0 \pm 1.7^{b}$ & $77.3 \pm 17.5^{b}$ & $139 \pm 104^{b}$ & $52.3 \pm 11.9^{\mathrm{c}}$ & $154 \pm 102^{b}$ \\
\hline
\end{tabular}

* concentration $<$ detection limit.

Differences among the concentrations in WSP from the four locations are indicated by superscripts; means sharing the same superscript are not significantly different among sampling stations $\left(\mathrm{p}_{\text {Tukey }}>0.05\right)$. 
Table 5. Element concentrations (mean $\pm \mathrm{SD}$ or range; $\mu \mathrm{g} \mathrm{g}^{-1}$ dry wt) in clams and oysters from tropical and subtropical areas.

\begin{tabular}{|c|c|c|c|c|c|c|c|c|c|c|}
\hline Species & Location & Ag & $\overline{\text { As }}$ & $\mathrm{Cd}$ & Co & $\mathrm{Cr}$ & $\mathrm{Cu}$ & Mn & $\mathbf{N i}$ & $\mathbf{Z n}$ \\
\hline Clams & & & & & & & & & & \\
\hline Gafrarium tumidum $^{1}$ & Hong-Kong & & & & & 0.67 & 5.77 & & 5.59 & 57.5 \\
\hline G. tumidum $^{2}$ & Fiji & & & & $1.0-2.8$ & $1.0-1.6$ & $4.2-11.0$ & $28-45$ & $1.7-4.5$ & \\
\hline Anadara antiquate $^{2}$ & Fiji & & & & $0.9-2.5$ & $0.8-1.8$ & $4-13$ & $32-50$ & $2-4$ & \\
\hline Chione subrugosa $^{3}$ & Tropical mangrove lagoon & & & $\begin{array}{c}0.72 \pm 0.09- \\
2.25 \pm 0.5\end{array}$ & $\begin{aligned} 0.13 & \pm 0.14- \\
1.1 & \pm 0.17\end{aligned}$ & $\begin{array}{c}1.48 \pm 0.28- \\
1.93 \pm 0.53\end{array}$ & $\begin{array}{c}20.8 \pm 1.49- \\
23.4 \pm 1.43\end{array}$ & $\begin{array}{c}4.08 \pm 0.21- \\
4.55 \pm 0.08\end{array}$ & $\begin{array}{c}2.32 \pm 0.35- \\
2.65 \pm 0.46\end{array}$ & $\begin{array}{l}51 \pm 4- \\
73 \pm 11\end{array}$ \\
\hline Circe sinensis ${ }^{1}$ & Hong-Kong & & & & & 2.26 & 3.13 & & 2.8 & 43.7 \\
\hline Codakia orbicularis ${ }^{4}$ & Dominican Republic & & & 3.8 & & 1.66 & 3.08 & & 1.57 & 22.9 \\
\hline Ruditapes philippinarum ${ }^{1}$ & Hong-Kong & & & & & 0.9 & 3.99 & & 4.66 & 98 \\
\hline Tellina fausta ${ }^{4}$ & Dominican Republic & & & 0.04 & & 4.15 & 14.1 & & 4.91 & 51.4 \\
\hline $\begin{array}{l}\text { Circentia callipyga }{ }^{5} \\
\text { Oysters }\end{array}$ & Qatar & 3.03 & 156 & 1.17 & 4.45 & 0.97 & 8.35 & 17.7 & 23.9 & 69.1 \\
\hline Isognomon isognomon $^{6}$ & Phuket, Thailand & & & & & & $<150$ & & & $900-2,000$ \\
\hline I. alatus $^{7}$ & Malaysia & & & $\begin{array}{c}0.47 \pm 0.23- \\
3.71 \pm 0.12\end{array}$ & & & $\begin{array}{l}11 \pm 0.51- \\
30.7 \pm 0.8\end{array}$ & & & $\begin{array}{l}23.8 \pm 0.75- \\
334.5 \pm 12.5\end{array}$ \\
\hline I. alatus ${ }^{8}$ & Venezuela & & & $0.33-0.91$ & & $0.46-1.2$ & $14-49.1$ & & $11-18$ & $0.25-2.1$ \\
\hline I. alatus 9 & Colombian Caribbean & & & $0.8-15.6$ & & & $0.42-52.3$ & & & \\
\hline I. alatus 4 & Dominican Republic & & & $0.24-0.26$ & & $2.38-4.96$ & $7.58-19.7$ & & $1.25-2.90$ & $4,000-4,010$ \\
\hline I. alatus 10 & Guadeloupe & & & & & $0.23-7.2$ & $6.8-127$ & & & $1,060-12,160$ \\
\hline I. alatus ${ }^{10}$ & Martinique & & & & & $0.32-1.75$ & $5.4-248$ & & & $2,460-11,530$ \\
\hline I. bicolor ${ }^{9}$ & Colombian Caribbean & & & $0.98-6.99$ & & & $0.8-3.94$ & & & \\
\hline I. legumen ${ }^{11}$ & Taiwan & & & & & & $491 \pm 29$ & & & \\
\hline Isognomon sp. ${ }^{12}$ & Biscayne Bay, Florida & & $37.3 \pm 6.9$ & & & & & & & \\
\hline Ostrea sandvicensis ${ }^{13}$ & Hawaii & & & & & & 1,400 & & 20 & \\
\hline Saccostrea amasa ${ }^{14}$ & North Queensland, Australia & & & $1-12$ & & & & & & $673-20,906$ \\
\hline S. echinata ${ }^{15}$ & North Queensland, Australia & & & $0.69-2.34$ & & & & & & $2,080 \pm 453$ \\
\hline S. echinata ${ }^{16}$ & North Queensland, Australia & & & $0.198-4.63$ & & & & & & $325-4,680$ \\
\hline Crassostrea belcheri ${ }^{17}$ & Merbok estuary, Malaysia & & & & & & $1-8.5$ & & & $30-550$ \\
\hline C. cucullata $^{18}$ & Goa, India & & $2.3-6.3$ & & & & $251-728$ & $33.2-17.5$ & & $446-2,800$ \\
\hline C. echinata ${ }^{14}$ & Cleveland bay, Australia & & & & & & & & & $673-20,906$ \\
\hline C. gryphoides ${ }^{18}$ & Goa, India & & $3.2-5.8$ & & & & $175-210$ & & & $325-550$ \\
\hline C. iredalei $^{17}$ & Merbok estuary, Malaysia & & & & & & $4-8$ & & & $80-550$ \\
\hline C. gigas $^{19}$ & Derwent Estuary, Tasmania, & & & & & & & & & 38,700 \\
\hline C. virginica ${ }^{11}$ & Taiwan & & & & & & $257 \pm 196$ & & & $1,037 \pm 778$ \\
\hline
\end{tabular}

